\title{
Effect of collagen based protein isolate «Belkozine» on biological value of boiled sausages
}

\author{
Anatolii Ukrainets, Vasyl Pasichniy, \\ Maksym Polumbryk, Maniefa Polumbryk
}

National University of Food Technologies, Kyiv, Ukraine

Keywords:

Sausage

Protein

Pepsin

Trypsin

Belkozin

Article history:

Received 30.09.2016

Received in revised form 29.11.2016

Accepted 27.12.2016

Corresponding author:

Maksym Polumbryk

E-mail:

mx_pol@yahoo.com

DOI: $10.24263 / 2304-$

974X-2016-5-4-11

\section{Abstract}

Introduction. We have done comparative investigations of indispensable amino acids score of the proteins of boiled sausages, formulated with «Belkozine» and rate of tyrosine accumulation in the dynamic model of their digestion in human gastrointestinal tract in order to establish digestion level of the sausages .

Materials and methods. Hydrolysis has carried out in a special chamber consisted internal and external reservoirs. Internal part has a glass stirrer, which provided continuous mixing both fermented mass and dialysis of hydrolysis products. Duration of the two-step fermentation is 3 hours of each stage. Pepsin action was done on the first stage, whereas trypsin impact - on the second. Amino acids in protein containing foods have analyzed by ionexchange chromatography of protein hydrolysates.

Results and discussion. The comparative investigations of enzymatic hydrolysis of boiled sausages, made from thigh chicken meat and cooled to $0-4{ }^{\circ} \mathrm{C}$ have carried out. Trypsin has a positive effect on tyrosine formation. We were investigated the amino acids profile of the boiled sausages. It was found that, «Belkozine» inclusion into formulations of the boiled sausages didn 't cause significant changes in the amino acids content. Increase of «Belkozine» content resulted in the rise of tyrosine formation due to high availability of sausages proteins which has argued that this hydrocolloid has a positive impact on the ingestion degree of boiled sausages. The relationships between duration of hydrolysis and concentration of tyrosine, which is being formed during hydrolysis, has been established on the basis of experimental data.

Conclusions. Increase of this hydrolysate concentration from 6 to $12 \%$ in the formulation give rise tyrosine formation as a result of sequential enzymatic hydrolysis in the pepsin-trypsin system, which in vitro simulates ingestion processes occuring in humans bodies. Therefore, «Belkozine» utilization in boiled sausages formualtions allows to increase their bilogical value. 


\section{Introduction}

Increased food production often resulted in loss of biological value of the final products due to concentration decrease of several important nutrients, such as essential fatty and aminoacids, macro- and microelements and others [1]. Thus, improvement of food technologies in order to increase their biological value is a still relevant for the manufacturers and consumers. Meat technologies take an important place in the diet for some specific groups, since products made from meat are the main source of amino acids in a human diet [2]. However, meat products, especially boiled sausages vary in their stability to provide all of the essential amino acid in amounts needed to meat human requirements. It has been shown, that boiled sausages can provide relatively complete proteins.

The methodology to measure the quality of dietary proteins for humans has been discussed for a long period of time. Protein Digestibility Corrected Amino Acid Score (PDCAA Score) was recommended by FAO/WHO as the preferred method to evaluate dietary protein quality $[3,4]$. Unfortunately, the true digestibility of the proteins is always higher, than apparent value since digestibility measurements take into account the fecal protein [5]. Thus, several gastrointestinal models, simulating gastrointestinal transit of food and digestive processes in the stomach and small intestine have been proposed $[6,7]$. In this work we were applied dynamic in vitro amino acids digestibility model, which has been validated for the digestion of a broad range of food products, including dairy, wheat and fish products $[5,8,9]$.

Inclusion of collagen containing protein «Belkozine» in the boiled sausages formulations can improve sensory and functional properties of the final products as well as partly compensate loss of essential aminoacids, which is usually occurs at the partial meat content decrease in the formulation [10]. We have used enzymatic hydrolysis method to investigate in vitro the effect of using «Belkozine» on ingestion degree of proteins of boiled sausages. This method can simulate the processes which occur in gastrointestinal tract of humans [11-13]. According to the method, protein containing samples were subjected to the proteolytic enzymes action, which were included pepsin and trypsin at the constant release of hydrolysis products by dialysis $[11,12]$.

\section{Materials and methods}

\section{Materials}

$\mathrm{HCl}, \quad \mathrm{NaOH}, \quad \mathrm{Na}_{2} \mathrm{CO}_{3}, \quad \mathrm{NaHCO}_{3}, \quad \mathrm{Na}_{2} \mathrm{C}_{4} \mathrm{H}_{4} \mathrm{O}_{6}, \quad \mathrm{CuSO} 4 \cdot 5 \mathrm{H}_{2} \mathrm{O}, \quad \mathrm{Na}_{2} \mathrm{WO}_{4} \cdot 5 \mathrm{H}_{2} \mathrm{O}$, $\mathrm{Na}_{2} \mathrm{MoO}_{4} \cdot 5 \mathrm{H}_{2} \mathrm{O}$ were offered from Sigma-Aldrich. Unless specific notifications, all the chemicals were analytical reagent grade without further purification. Crystalline pepsin and trypsin were obtained from Biopharm Co. (Kyiv, Ukraine). The semi-permeable (cut-off of 5-7 $\mathrm{kDa}$, surface area $0,7 \mathrm{~m} 2$ ) was introduced in the bottom part of the digestibility compartment.

The chicken thigh meat was obtained from "Nasha Ryaba". The thigh meat was deboned and skinned before being stored under vacuum at $-20{ }^{\circ} \mathrm{C}$ and was used within a 10 days of storage. Dry beef isolate «Belkozine» was obtained from Belkozine Co. (Pryluky, Ukraine) Carboxymehtylcellulose (CMC), Xanthan gum, guar gum, soybean isolate, whey protein isolate, soybean isolate, salt, sodium nitrite were obtained from Roeper Co. (Germany). Silicagel A300 was sourced from Shandong Sinchem Silica Gel (China). Aromatizer "Frankfurter`s sausages" was obtained from local supermarket "Auchan". 


\section{Set-up of the in vitro digestion experiments}

Hydrolysis has carried out in a special chamber consisted internal and external reservoirs. Internal part has a glass stirrer, which provided continuous mixing both fermented mass and dialysis of hydrolysis products. Duration of the two-step fermentation is 3 hours of each stage. Pepsin action was done on the first stage, whereas trypsin impact on the second [11].

The ingestion procedure was modified [12]. The sample, containing approximately 150 $\mathrm{mg}$ of protein was subjected into internal vessel, having semipermeable membrane in the bottom part. After that, $15 \mathrm{ml}$ of $0,02 \mathrm{M}$ hydrochloric acid $(\mathrm{pH}=1,7)$ was added into the internal vessel and external vessel was filled with $60 \mathrm{ml}$ of $0,02 \mathrm{M} \mathrm{HCl}$ in order to maintain ionic potential similar to that of internal vessel. Further, internal vessel has put into external vessel, so as the level of both liquids were the same. The samples were incubated at $37^{\circ} \mathrm{C}$. Crystalline pepsin $(15 \mathrm{mg})$ was added into the internal, when temperature will reach this value. Thus, pepsin concentration $(1 \mu \mathrm{g} / \mathrm{ml})$ in the internal vessel was similar to that of gastric juice at the ingestion of food. The reaction mixture was constantly stirred at $60 \mathrm{rpm}$. Duration of enzymatic hydrolysis in acidic conditions was 3 hours. After that, solution of external vessel was changed from acidic to base by $0,02 \mathrm{M} \mathrm{NaHCO}_{3}$ addition, whereas protein containing slurry in the internal vessel was neutralized by means of $2 \mathrm{M} \mathrm{NaOH}$ solution addition, $\mathrm{pH}$ value should be 8,2 . Further, internal vessel was diluted by $15 \mathrm{ml}$ of $0,02 \mathrm{M} \mathrm{NaHCO}_{3}$ solution which provided an opportunity to obtain buffer solution and 15 $\mathrm{mg}$ of trypsin was added. The procedure of incubation by trypsin was similar to that of pepsin and terminated after 3 hours. The samples were taken from external solution each hour of enzymatic hydrolysis [12].

Tyrosine concentration in these samples was determined photometrically at the appropriate absorbance wavelength $(\lambda=750 \mathrm{~nm})$ according with the procedure, which is widely used for this purpose [14]. The calibrating plot of standard solution of tyrosine versus optical density, when values of optical density of the standard solutions was measured and finally concentration of tyrosine has determined.

\section{Amino acids profile analysis and PDCAA score calculation}

Amino acids in protein containing foods have analyzed by ion-exchange chromatography of protein hydrolysates. The procedure of hydrolysis was the following: the sample of boiled sausage $(2 \mathrm{mg})$ was placed into the thermo resistant flask and $1 \mathrm{ml}$ of 6 $\mathrm{M} \mathrm{HCl}$ was added. After that, flask was hermetically sealed and retained at $110^{\circ} \mathrm{C}$ during 24 hours with nitrogen blanketing. Following hydrolysis, the ion exchange chromatography was used with post column ninhydrin derivatization for detection. Cystine was oxidized to cysteic acid by rhe sample treating with performic acid solution at for $0{ }^{\circ} \mathrm{C}$ for 16 hours. After that, the sample was hydrolyzed with $6 \mathrm{M} \mathrm{HCl}$ at $110^{\circ} \mathrm{C}$ during 18 hours. Cysteic acid was separated on an ion-exchange column post-column ninhydrin derivatization.

Amino acids results were converted to $\mathrm{mg} / 100 \mathrm{mg}$ protein using nitrogen to protein conversion factor of 6.25. Amino acid ratios (milligrams of an IAA (indispensable amino acids) in $1.0 \mathrm{~g}$ of test protein per milligram of the same IAA in $1.0 \mathrm{~g}$ of reference protein 100) for IAA are calculated by using the FAO/WHO suggested pattern of amino acid requirements as the reference protein for all ages except for infants. This pattern contains, in milligrams per gram of protein: histidine, 19; isoleucine, 28; leucine, 66; lysine, 58; methionine + cystine, 25; phenylalanine .tyrosine, 63; threonine, 34; tryptophan, 11; and valine, $35[1,3,4]$.

Amino acids content was measured according with Moor and Stein method by means amino acids analyzer T 339 (Czech Republic) [15]. Eluted amino acids were measured by 
reaction with ninhydrin and spectrophotometric determination at $570 \mathrm{~nm}$ for $\alpha$ amino acids and $440 \mathrm{~nm}$ for proline.

The values of Amino acids score and tyrosine concentration were obtained with statistical significance set at $\mathrm{P}<0.05$.

\section{Results and discussion}

The boiled sausages with different «Belkozine» content in the Protein Stabilizer (PS) were manufactured in order to evaluate effect of this additive on digestion degree. The developed composition of PS has the following components, \%: carboxymethylcellulose 5 , guar gum -10 , xanthan gum -5 , whey isolate -20 , collagen containing protein «Belkozine» - 60. The functional and technological properties of the sausages were improved by silica dioxide (A300) addition into the formulation in the form of nanocomposite at the level of $0,3 \%$ to the total mass of mixture [10].

We have done comparative investigations of enzymatic hydrolysis of boiled sausages, made from chicken meat and cooled to $0-4{ }^{\circ} \mathrm{C}$. In our previous works we have developed formulations of boiled sausages with different PS content. Formulations of these boiled sausages are given in the Table 1 .

Content of the forcemeat systems, \%

Table 1

\begin{tabular}{|l|c|c|}
\hline \multicolumn{1}{|c|}{ Raw materials } & Sample 1 & Sample 2 \\
\hline Chicken thigh meat & 80 & 60 \\
\hline Protein Stabilizer & 10 & 20 \\
\hline Soybean isolate & 10 & 20 \\
\hline Water, to the total mass & 30 & 30 \\
\hline Salt, to the total mass & 2,2 & 2,2 \\
\hline
\end{tabular}

Since $20 \%$ of the developed PS are not the proteins and $20 \%$ is a soybean isolate, the health benefit of the developed compositions and final sausages may at first sight appear questionable. Thus, comprehensive research of digestibility of the developed sausages is necessary.

Table 2 compares the amino acids profile. The data shown in the table have suggested, that «Belkozine» inclusion into formulations of the boiled sausages didn`t cause significant changes in the amino acids content. The sample of boiled sausages, contained $10 \%$ of protein stabilizer has similar amino acid score with the control sample. In other words, decrease of meat content in the formulation has no negative impact on essential amino acids score in the final sausages. Taking to account these data, we have concluded about noticeable compatibility between thigh chicken meat and dry beef collagen containing protein «Belkozine» in the technology of boiled sausages. Further increase of PS level resulted in the negligible decrease of valine score, which is a limiting amino acid in the samples of sausages. Therefore, further increase of «Belkozine» content in the formulations is not desirable due to possible negative effect on amino acids profile. 
Table 2

Protein content and Indispensable Amino Acids compositions of the samples of boiled sausages

\begin{tabular}{|l|c|c|c|c|c|c|}
\hline \multirow{2}{*}{ Amino acid } & \multicolumn{2}{|c|}{ Control } & \multicolumn{2}{c|}{$\begin{array}{c}\text { Sample with 10\% } \\
\text { PS }\end{array}$} & $\begin{array}{c}\text { Sample with 20\% } \\
\text { PS }\end{array}$ \\
\cline { 2 - 7 } & $\%$ & $\begin{array}{c}\text { IAA } \\
\text { Score, } \%\end{array}$ & IAA & \% & $\begin{array}{c}\text { IAA } \\
\text { Score, } \%\end{array}$ \\
\hline Lysine & 8,55 & 155,0 & 8,46 & 154,0 & 8,44 & 153,0 \\
\hline Histidine & 2,71 & - & 2,73 & - & 2,75 & - \\
\hline Arhinine & 6,18 & - & 6,25 & - & 7,13 & - \\
\hline Aspartic acid & 9,51 & - & 9,45 & - & 8,99 & - \\
\hline Threonine & 4,78 & 118,0 & 4,68 & 117,0 & 4,48 & 112,0 \\
\hline Serine & 5,26 & - & 5,32 & - & 5,33 & - \\
\hline $\begin{array}{l}\text { Aminoglutaric } \\
\text { acid }\end{array}$ & 18,6 & - & 18,66 & - & 18,78 & - \\
\hline Proline & 6,48 & - & 6,40 & - & 5,58 & - \\
\hline Glycine & 4,88 & - & 4,90 & - & 5,02 & - \\
\hline Alanine & 6,34 & - & 6,24 & - & 6,10 & - \\
\hline Cystine & 1,2 & 114,0 & 1,22 & 114,0 & 1,34 & 114,0 \\
\hline Valine & 3,65 & 72,0 & 3,60 & 72,0 & 3,53 & 71,0 \\
\hline Methionine & 2,86 & - & 2,76 & - & 2,63 & - \\
\hline Isoleucine & 3,08 & 79,0 & 3,16 & 79,0 & 3,26 & 82,0 \\
\hline Leucine & 8,11 & 116,0 & 8,15 & 116,0 & 8,27 & 118,0 \\
\hline Tyrosine & 3,75 & 133,0 & 3,80 & 134,0 & 3,92 & 139,0 \\
\hline Phenilalanine & 4,12 & - & 4,22 & - & 4,45 & - \\
\hline Total & 100,0 & - & 100,0 & - & 100,0 & - \\
\hline
\end{tabular}

The data shown in the table 2 has been used in the next step of our investigations, there we were studied digestibility of sausages in the dynamic in vitro model. As it can be seen from the table 2, increase of the «Belkozine» content in the formulated sausages cause rise of tyrosine residue content. Thus, we were expected that it would be mirrored in the data, obtained from this model.

It is well known that the peptides and free amino acids being released into solution as a result of hydrolysis of protein containing products $[1,3,9,10]$. Therefore, the total quantity of amino acids is determined in the processes, which modeling in vitro ingestion of foods $[10,11]$. According to the Lowry protein assay, tyrosine concentration was determined by means of spectrophotometric devices.

We were compared an impact of way of protein stabilizer addition on the ingestion degree of proteins. PS was mixed with the forcemeat emulsion in hydrated form and as a dry powder. It has been found that the enzymatic hydrolysis rapidly proceeded in the sausages, formulated with dry PS, especially at the stage of trypsin action (Figure 1 and 2). In our opinion it may related to the formation of the more dense texture due to the rapid swelling of collagen in the sausages made with hydrated «Belkozine» based stabilizer. 


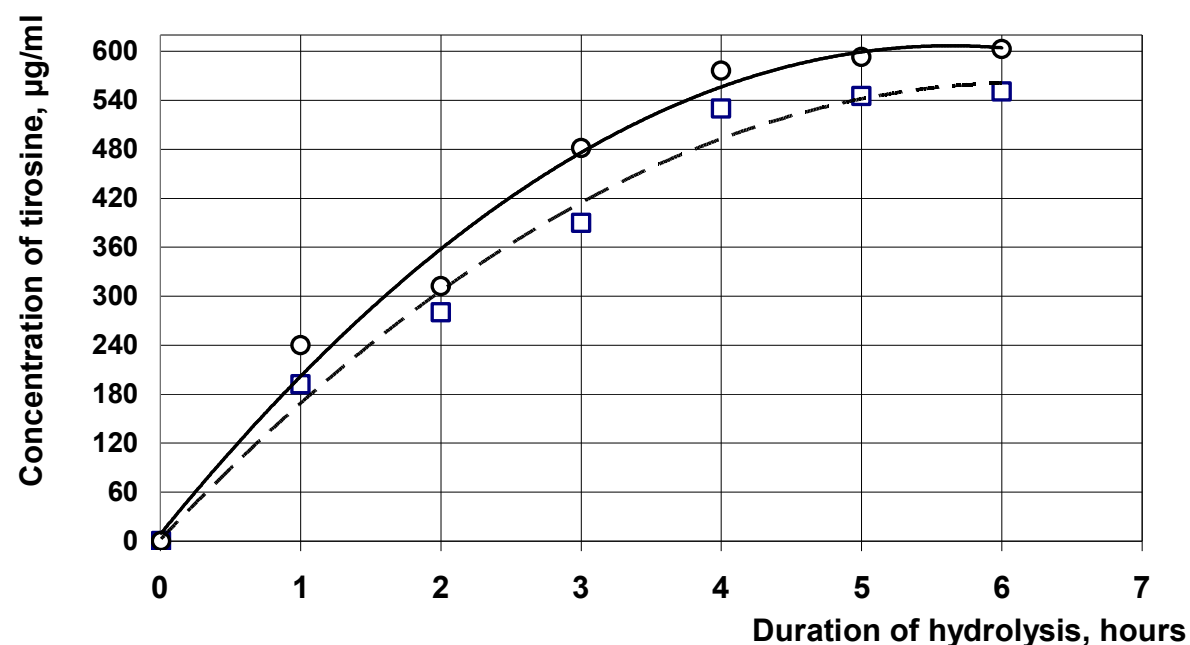

口Sample with $10 \%$ of PS

o Sample with $20 \%$ of PS

Figure 1. Tyrosine accumulation during enzymatic hydrolysis of boiled sausages, manufactured with dry PS

Relatively high quantity of tyrosine at the initial stage of pepsin enzymatic hydrolysis has observed in the sausages made with dry PS. It can be explained by the primary hydrolysis at the surface of the sausages, whereas trypsin reacted with low molecular peptides.

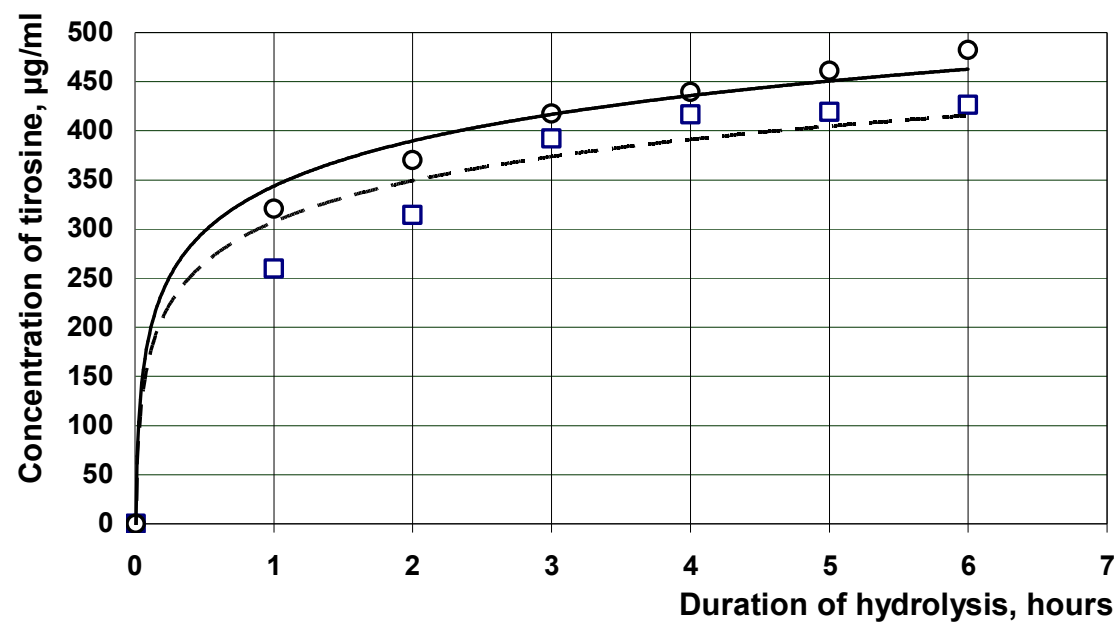

口Sample with $10 \%$ of PS

o Sample with $20 \%$ of PS

Figure 2. Tyrosine accumulation during enzymatic hydrolysis of boiled sausages, manufactured with hydrated PS 
As it can be seen from Figure 1 and 2, rise of «Belkozine» content resulted in the increase of tyrosine formation due to high availability of sausages proteins which has argued that this hydrocolloid has a positive impact on the ingestion degree of boiled sausages. These results were explained by the greater tyrosine residues content in collagen containing protein «Belkozine» compared with those in raw meat and soybean isolate.

The relationship between duration of hydrolysis $(t)$ and concentration of tyrosine $(C)$, which is being formed during hydrolysis, has been established on the basis of experimental data. It can be described by the following equations:

$\mathrm{C}=60,6 \ln (\mathrm{t})+307,2$ (for the boiled sausages, formulated with hydrated PS at a level of $10 \%)$

$\mathrm{C}=66,4 \ln (\mathrm{t})+343,7$ (for the boiled sausages, formulated with hydrated PS at a level of $20 \%$ )

$C=-14,7 t^{2}+181,3 t+1,7$ (for the boiled sausages, formulated with dry PS at a level of $10 \%)$

$\mathrm{C}=-18,8 \mathrm{t}^{2}+212,3 \mathrm{t}+1,7$ (for the boiled sausages, formulated with dry PS at a level of $10 \%) ; r^{2}=0,9991$

\section{Conclusions}

Thus, on the basis of results of investigations, we have concluded about significant improvement of ingestion degree of boiled sausages manufactured with dry beef protein «Belkozine». Increase of this hydrolysate concentration from 6 to $12 \%$ in the formulation give rise tyrosine formation as a result of sequential enzymatic hydrolysis in the pepsintrypsin system, which in vitro simulates ingestion processes occuring in humans gastrointestinal tract. Therefore, «Belkozine» utilization in boiled sausages formualtions allows to increase their bilogical value.

\section{References}

1. Caballero P., Finglas L., Trugo S., et.al. (2004), Encyclopedia of food sciences and nutrition, $4^{\text {th }}$ edition, 2004, Academic Press, Oxford.

2. Jakobsen L., Kondrup J., Zellner M. (2011), Effect of a high protein meat diet on muscle and cognitive functions: A randomised controlled dietary intervention trial in healthy men, Clinical Nutrition, 30, pp. 303-311.

3. FAO/WHO. (1991), Protein Quality Evaluation; Report of a Joint FAO/WHO Expert Consultation, United Nations; Rome, Italy, [Text], available at: www.fao.org/ag/humannutrition/35978-02317b979a686a57aa4593304ffc17f06.pdf.

4. Hughes H., Ryan D., Mukherjea R., Schasteen C. (2011), Protein digestibilitycorrected amino acid scores (PDCAAS) for soy protein isolates and concentrate: criteria for evaluation, J. Agricultural and Food Chemistry, 59, pp. 12707-12712.

5. Havenaar R., Maathius A., De Jong A., et.al. (2017), Herring roe protein has a high digestible indispensable amino acid score (DIAAS) using a dynamic in vitro gastrointestinal model, Nutrition Research, (in press).

6. Moreno F.J., (2007), Gastrointestinal digestion of food allergens: effect on their allergenicity, Biomedical Pharmacotherapy, 61, pp. 50-60. 
7. Wickham M., Faulks R., Mills C. (2009), In vitro digestion methods for assessing the effect of food structure on allergen breakdown, Molecular Nutrition and Food Research, 53, pp. 952-958.

8. Nabil S., Gauthier S., Drouin R., Poubelle P., Pouliot Y. (2011), In vitro digestion of proteins and growth factors in a bovine whey protein extract as determined using a computer-controlled dynamic gastrointestinal system (TIM-1), Food Digestibility, 22, pp. 13-22.

9. Framroze B., Savard P., Gagnon D., Richard V., Gauthier S. (2014), Comparison of nitrogen bioaccessibility from salmon and whey protein hydrolysates using a human gastrointestinal model (TIM-1), Functional Foods and Health Disorders, 4, pp. 222231.

10. Ukrainets A.I, Pasichniy V.M., Zheludenko Y.V., Polumbryk M.M. (2016), Influence of protein containing compositions with high amount collagen containing stabilizer on boiled sausages quality, scientific and practical journal «Food science and technology», 10(3), pp. 50-55.

11. Antipova L., Glotova I., Rogov I. (2001), Research methods in meat and meat products, Kolos, Moscow.

12. Pasichnyi V., Yastreba Y. (2010). Investigations of enzymatic ability of the plant protein containing fillers for canning patties manufacturing, Scientific bulletin of Gzhytsky LNUVCMIB, 3(45), pp. 50-53.

13. Kananen A., Savolainen J., Makinen J. (2000), Influence of chemical modification of whey protein conformation on hydrolysis with pepsin and trypsin, International Dairy Journal, 10, pp. 691-697.

14. Olson B., Markwell J. (2007), Assays for determination of protein concentration, Current Protocol in Protein Science. [Text], available at: onlinelibrary.wiley.com/doi/10.1002/0471140864.ps0304s48.

15. Spackman D., Stein H., Moore S. (1958), Automatic recording apparatus for use in chromatography of amino acids, Analytical Chemistry, 30, pp. 1190-1206. 